\title{
Grammatical Tenses and Communicative Intentions: A case study of the German Perfekt and Präteritum
}

Valentina Concu

Assistant Professor. Universidad del Norte, Barranquilla, Colombia.

Received: July 2020; Accepted: February 2021

\begin{abstract}
Recent research in syntax and corpus linguistics has shown how the German Perfekt (present perfect) and Präteritum (simple past) are widely used in written language-even though these tenses are commonly described in DAF (German as a foreign language) materials as used respectively in the spoken and written forms. While these analyses only focus on written corpora, an extensive study on the use of tenses in spoken interaction is still missing. In this paper, I try to fill this gap in the literature by exploring the use of Perfekt and Präteritum in the recordings of the Frankfurt Auschwitz trials, held in Frankfurt am Main, from December 20, 1963, to August 19, 1965, and available on the web page of the Fritz Bauer Institute. Textual analyses of the depositions of five former German prisoners of the Polish concentration camp show that German native speakers use both tenses in their spoken interactions. These results widely contradict their depiction in DAF materials, textbooks, and grammars. Furthermore, the types of Präteritum found are far more diverse than is traditionally held by scholars, who claimed that the use of this tense in spoken language is limited to verbs such as sein (to be), haben (to have) and modals, such as können (can), müssen (must), sollen (should), etc. The outcome of this study shows how the difference between Perfekt and Präteritum is determined by the subjective attitude of the speakers in relation to the information they want to convey.
\end{abstract}

Keywords: Pragmatics, Tenses, Perfect, Preterite, German

\section{INTRODUCTION}

Generally, the correct use of grammatical tenses is one of the first and most important didactic goals of every foreign language curriculum, since it allows the understanding of every written or spoken text. The tense system of a language is, indeed, a vital part of communication, and "the language itself requires us to use tenses in every sentence and often, more than one time" (Weinrich $1964,8)$. Because of their vital role in communication, grammatical tenses also occupy a special place in SLA research. According to Nicole Schumacher (2005), the use of the German Perfekt (present perfect) and Präteritum (simple past) is one of the most complex learning topics in DAF (Deutsch als Fremdsprache-German as a foreign language). The German past tenses are definitively a problematic issue for students in language classrooms, and the reasons for this are numerous. First, the didactic materials used at schools and universities do not offer adequate explanations; they often refer to the register (spoken vs. written) as the main difference between these two tenses. Second, linguistic research in this field still appears to be dominated by the tense model developed by Hans Reichenbach in 1947, in which grammatical tenses are viewed as a mere representation of the objective categories of the present, past, and future (Concu 2016). This model uses three different points to describe any given tense: point of speech, point of reference and point of event. The point of speech (S) is the moment in which the speaker or writer actually says or writes something, the point of event (E) refers to the exact moment in which the particular event took place, and the point of reference $(\mathrm{R})$ is the time expressed by the conjugated verb form and is often specified by temporal adverbs.

To describe the German present perfect, for instance, scholars such as Ehrich (1992), Helbig \& Buscha (1998), 
Schumacher (2005) and Rothstein (2007) claim that the point of speech is at the same point as the point of reference in the temporal axis, a feature that the present perfect shares with the present. The point of event is back on the same axis, since the past participle situates the action before the time in which the speaker or writer talks about it. Reichenbach's parameters suggest that this tense is able to express a resultative and punctual meaning only, since the action, independently from the verb used, is situated before the moment of speech. However, this depiction fails to account for the frequent appearance of the present perfect with present and future temporal references, as shown in the following examples:

(4) Er hat sich damit jetzt als Politgangster entlarvt

He has himself with that now as Politgangster revealed 'He revealed himself now to be a politgangster'

(5) Gleich habe ich es geschafft. Soon have I it achieved 'I will achieve it soon' (Schumacher, 2005, 158, 161)

Instances such as the ones in (4) and (5) indicate that questions addressing the meaning and the functions of the present perfect are largely discordant.

As observed by Alessandra Lombardi (2008) in her work, Tempus der Wissenschaft, "die Ermittlung der semantischen Grundwerte der Tempi, von Anfang an im Mittelpunkt des Interesses deutscher und italienischer Tempusforschung, hat sich als echte wissenschaftliche Herausforderung erwiesen, welche zu inhomogenen und noch bis heute umstrittenen deskriptiven Ergebnissen (Tempusdarstellungen) geführt hat" (p. 142) [The representation of the German tenses, which was from the beginning the center of the interest of Italian and German tense's research, became a real scientific challenge, which led to controversial and inhomogeneous descriptive results].

The large divergence in methodologies and frameworks around the use of the German Perfekt and Präteritum in written and spoken contexts, and the misleading representations of the tenses in DAF material influence the correct depiction of the meanings of these two tenses. This work seeks to address the issues related to the use of the two tenses in spoken language to gain a better understanding of their usage by German speakers. To achieve this goal, I will focus exclusively on spoken language and use a particular corpus of spoken texts: the recordings of the Frankfurt Auschwitz trials held in Frankfurt am Main, from December 20, 1963, to August 19, 1965, and available on the web page of the Fritz Bauer Institute. The decision to use this corpus for the current study was driven by several reasons. First, these recordings offer a large amount of spontaneous spoken language texts in which the interactions between the interlocutors are formal. Second, due to the nature of the trials, speakers are required to describe events in the past that happened almost twenty years before the trials. Third, the cultural and historical value of these trials makes it a unique corpus to work on. These reasons make this corpus the most suitable one for the aim of this research. Specifically, in this paper, I addressed:
1. the use of the German Perfekt and Präteritum in spoken language,

2. the relation between pragmatics and tense use.

This paper is organized as follows. The first substantive section offers a review of the literature. The second describes the methodology used to collect data from the corpus. The third section presents and discusses the results. In the last section, the implications of this analysis will be discussed in terms of future research on the use of these tenses in spoken language.

\section{REVIEW OF THE LITERATURE}

The first scientific work that accounts for tenses and pragmatics is the one by Weinrich (1964), Tempus: besprochene und erzählte Welt, in which he divides German tenses into two different groups, depending on the intentions of the speakers or the writers. If the information is intended to be part of the narration, speakers use the tenses of the narration group (erzählte Welt), which are Präteritum and Perfekt. If the information is more like a claim, or speakers want to discuss a piece of particular information or feel particularly engaged with what they are stating, they will use the tenses of the commentary group (besprochene Welt), which are the Präsens and the Perfekt. These two categories emphasize the strong connection between pragmatics and the use of tenses and go beyond the traditional depictions of tenses as mere temporal indicators. Other scholars, such as Park (2003), Schumacher (2005) and Welke (2010) also refer to Weinrich's depictions of German tenses in their works. Park (2003) claims that speakers carry out three different functions with the verbal tenses: the report, the expectations, and the nomik functions (p. 26), highlighting the strict connections between pragmatics and tenses semantic. Schumacher (2005) makes a direct reference to Weinrich's work when she claims that "the difference between present perfect and preterite lies in the subjective dimension of 'DISTANCE," which refers to Weinrich's categories of comment and narration (p. 191). In the same way, Welke (2010) argues that the German Perfekt is the past tense of the comment because of its semantic features, while the German Präteritum is the past tense of the narration because of its semantic features

Concu (2016) shows how these categories better reflect the speakers' use of tenses in Modern German. She analyzed a corpus of 25 articles from the issue of November 2013 of the famous magazine Der Spiegel. In her study, she observed how, even in the same article, writers combine commentary and narrative parts, and how in the first they use a high number of Präsens and Perfekt, while in the second they use a large amount of Präteritum and Plusquamperfekt. The communicative intents of the authors of the articles were reflected in the particular tenses they choose. Of particular interest in those articles was also the use of the Perfekt and Präteritum in the same sentence, as shown in the next two examples: 
(1) "In der Wahrnehmung der Bürger ist die einst liberale FDP zu einer Wirtschaftspartei geworden die sich vor allem um die Interessen einer einzelnen Gruppe kümmerte, die des Mittelstands".

'In the perception of the citizens, the liberal FPD has become a business party, which took care of the interest of a single group, the middle class'

(2) "Er hat das Gebetsfrühstück eingerichtet, so wie andere Menschen einen Adventsbasar einrichten."

'He has set up the prayer breakfast, as the other set up an advent bazar'

\section{METHODOLOGY}

The corpus of this study includes five recordings from the Frankfurt Auschwitz trials, one of the largest trials against the Nazi regime in history, which were held in the city of Frankfurt from December 20, 1963, to August 19,1965 , against 22 of the SS soldiers that worked in the Auschwitz concentration camp. The leading judge was Fritz Bauer, also a former prisoner of the camp. Among the charged soldiers were high ranked SS officers, Gestapo members, and Kapo, such as Wilhelm Boger, Victor Capesius, Franz Lucas, Oswald Kaduk, and Robert Mulka. The trials summoned around 360 witnesses, 210 of them were camp survivors from all over Europe. Their depositions covered different aspects of life in one of the biggest death camps ever built by the Nazi regime. During the months in which the trials were held, the judges also traveled personally to the concentration camps, to gain a better understanding of the depositions of the witnesses. A lot of the accused, at the end of the trials, were charged with capital punishment or with long-term imprisonment.

The depositions included in this study are from 5 former prisoners ( 1 female, 4 males) and people close to the charged officers. All five witnesses were native speakers of German. The length of their depositions ranged from ca. 2,500 (Pickard Elisabeth) to ca. 45,000 (Otto Wolken) words. From each deposition, I looked at both the type and the tokens of the verbs used in Perfekt and Präteritum. For the textual analyses, I used the online software Voyant (available at http://voyant-tools. org). The software displays frequency counts for every word in the text, as well as co-occurrence charts. These charts are especially helpful for the distinction between the use of the verbs haben (to have) and sein (to be) as full verbs (in sentences that could be translated into English as I have no memories about that, and I'm German) or as auxiliaries (for the Perfekt and Plusquamperfekt constructions). Since these verbs can appear in both tenses, the software helps to discern their functions in a given sentence and to indicate their forms (i.e., present perfect and preterite, excluding, for instance, the form of past participles).

I will present the results as follows:

1 The first set of charts will display the count of the tokens in Präteritum and Perfekt. The total frequency was calculated counting every time a token of a given verb was found, regardless of its use in the first, second third-person singular or plural.

2 The second set of charts will contain a comparison of the times the four most frequent verbs in the corpus were used in Perfekt and Präteritum.

3 The third set of charts will display some of the types of verbs in both tenses that were used with a very low frequency (once and twice). This last section of the analysis aims to look at the data from a different perspective and to challenge the traditional approach by scholars such as Weerning \& Mondello (2004), who claimed that the use of the Präteritumin spoken language, for instance, is limited to verbs such as sein (to be), haben (to have) and modals, such as können (can), müssen (must), sollen (should), etc.

\section{THE TEXTUAL ANALYSIS OF THE RECORDINGS}

In this section, I will present the result of the textual analysis of the five depositions. The first set of charts, one for every recording, displays the numeric count of tokens for each form of Präteritum and Perfekt that was found, together with the most frequent verbs used in each tense.

1. Elisabeth Pickard

\begin{tabular}{|c|c|}
\hline Words & 2,558 \\
\hline Präteritum & 60 \\
\hline Perfekt & 88 \\
\hline
\end{tabular}

More frequent verbs used:

Präteritum: sein (to be) 51; sagen (to say) 7; wohnen (to live) 3,

Perfekt: kommen (to come) 2, bekommen (to receive) 2 .

2. Konrad Morgen

\begin{tabular}{|c|c|}
\hline Words & 22,432 \\
\hline Präteritum & 895 \\
\hline Perfekt & 441 \\
\hline
\end{tabular}

More frequent verbs used: Präteritum: sein (to be) 174; sagen (to say) 42; geben (to give/there is-there are) 13 ,

Perfekt: sein (to be) 40; sagen (to say) 34, hören (to hear) 11.

3. Otto Wolken

\begin{tabular}{|c|c|}
\hline Words & 43,233 \\
\hline Präteritum & 2,213 \\
\hline Perfekt & 828 \\
\hline
\end{tabular}


More frequent verbs used:

Präteritum: sein (to be) 518; kommen (to come) 77; stehen (to stand) 29,

Perfekt: sagen (to say) 87; sehen (to see) 61; machen (to do) 58.

4. Hermann Langbein

\begin{tabular}{|c|c|}
\hline Words & 35,811 \\
\hline Präteritum & 2,096 \\
\hline Perfekt & 1,091 \\
\hline
\end{tabular}

More frequent verbs used:

Präteritum: sein (to be) 616; können (can) 48; kommen 35 (to come); heißen (to be called) 20,

Perfekt: sagen (to say)104; sehen (to see) 77, sein 58 (to be).

5. Walter Petzold

\begin{tabular}{|c|c|}
\hline Words & 13,543 \\
\hline Preterite & 810 \\
\hline Perfekt & 363 \\
\hline
\end{tabular}

More frequent verbs used:

Präteritum: sein (to be) 175; können (can) 31; gehen (to go) 12 ,

Perfekt: sagen (to say) 39; sein (to be) 31, kommen (to come) 25.

The results of the frequency analyses of the tokens of both Perfekt and Präteritum in the depositions included in this study have shown that the number of Präteritum used is often larger than the amount of Perfekt forms found. Interestingly, the verbs that appear in both tenses with the highest frequency are similar, such as sein (to be), sagen (to say); kommen (to come), können (can), and gehen.

In the next set of charts, I analyze the most frequent verbs and how often speakers use them in Präteritum and Perfekt.

1. Elisabeth Pickard:

\begin{tabular}{|c|c|c|}
\hline Verb & Präteritum & Perfekt \\
\hline kommen & 1 & 2 \\
\hline sagen & 3 & 3 \\
\hline gehen & 0 & 2 \\
\hline sehen & 1 & 2 \\
\hline
\end{tabular}

2. Konrad Morgen:

\begin{tabular}{|c|c|c|}
\hline Verb & Präteritum & Perfekt \\
\hline kommen & 29 & 12 \\
\hline sagen & 53 & 34 \\
\hline gehen & 17 & 0 \\
\hline sehen & 9 & 17 \\
\hline
\end{tabular}

3. Otto Wolken:

\begin{tabular}{|c|c|c|}
\hline Verb & Präteritum & Perfekt \\
\hline kommen & 151 & 40 \\
\hline sagen & 32 & 83 \\
\hline gehen & 51 & 19 \\
\hline sehen & 16 & 61 \\
\hline
\end{tabular}

4. Hermann Langbein:

\begin{tabular}{|c|c|c|}
\hline Verb & Präteritum & Perfekt \\
\hline kommen & 87 & 43 \\
\hline sagen & 63 & 104 \\
\hline gehen & 22 & 8 \\
\hline sehen & 24 & 77 \\
\hline
\end{tabular}

5. Walter Petzold:

\begin{tabular}{|c|c|c|}
\hline Verb & Präteritum & Present perfect \\
\hline kommen & 13 & 25 \\
\hline sagen & 10 & 39 \\
\hline gehen & 15 & 2 \\
\hline sehen & 1 & 33 \\
\hline
\end{tabular}

The data in these charts show that the speakers use both verbs in the two tenses, such as sehen, even though some of them appear more frequently in Präteritum (such as kommen and gehen), while others tend to appear more frequently in Perfekt (such as sagen). Although the amount of data in this study is not enough to make some general claims, we are reminded of the pragmatic categories theorized by Weinrich (1964) and previously discussed. In this corpus, verbs such as kommen and gehen are often used to fit the narrative, whereas verbs such as sagen and sehen are deployed to make claims about given information. The next examples from the deposition of Konrad Morgen show the use of these verbs in this sense:

(3) "Es gingen dauernd Züge durch, Truppentransporte nach dem Osten, Verwundetentransporte kamen zurück." 
'Trains came constantly through, troops transportation to the Est, and wounded transports came back.'

(4) "Wer auf ein Kommando kam, der bekam die Schwerarbeiterzulage oder Langarbeiterzulage."

'The one who came into a commando, that one received an additional allowance for hard labor or the work in the camp.

(5) "Rabbiner und sonstige bedeutende jüdische Persönlichkeiten wurden sofort ausgesondert, ins Lager gebracht, in eine Baracke, die sie für sich hatten. Ich habe sie später gesehen, es stimmte."

'Rabbis and particular important Jewish celebrities were promptly selected, brought into the camp into a hut in which they had for themselves. I have seen them later on, it was true.'

(6) "Und später hat man dann-das habe ich auch gesehen-Gleise direkt in das Vernichtungslager gelegt". 'And later they have then-I have also seen it-put tracks that go directly to the extermination camp'.

(7) "In diesem Zusammenhang eine Frage: [Pause] Nachdem Sie das hier uns so klar gesagt haben und das erklärt haben-ich nehme das an, daß es Ihr damaliges Wissen ist, was Sie uns gesagt haben über den Vernichtungsbefehl -, haben Sie, als Sie festgestellt hatten, daß in Auschwitz Vergasungen vorkamen, und zwar Massenvergasungen, das in Ihrem Bericht auch erwähnt".

'Concerning this, a question: [pause] After you have clearly said it to us and have explained it-I assume that this was your knowledge at the time, what you have said to us about the order to exterminate-you have when you had figured it out, that in Auschwitz gassing occurred, namely thousands of gassing, that you mention in your report.'

(8) "Nun sagte sich Waldeck: Leute, denen ich gesagt habe, ihr werdet entlassen, die fliehen doch nicht".

"So, Waldeck said to himself: The people, to whom I have said, they will let you go, they won't escape after all".

Examples (3) and (4) display the use of the Präteritum for the narration of a particular event. Both examples contain only forms in this tense, which can be considered another indication of the narrative nature of this part. The examples in (5) also have verbs in Präteritum (together with some passive forms), but the claim by the speaker about having seen the selections of Rabbis and celebrities is expressed using the Perfekt. Example (6) differs from the previous one, in that all the verbs are in Perfekt. According to Weinrich (1964), the speaker here is making a claim about the constructions of tracks, which is reinforced using the verb sehen with the first-person pronoun. Example (7) has two forms of the verb sagen in Perfekt and it is a question that the judge asked the witness. As already mentioned, speakers tend to use the tenses of the commentary group when they want to make a claim or feel particularly engaged with the information they are conveying. In this example, the person who is posing the question has the intention to discover the truth about the events in the concentration camps and this could justify the use of the Perfekt. Example (8) is of particular interest. The witness is narrating a certain event and he introduced the reported speech by using the Präteritum form of sagen, whereas in the part that follows there is the same verb, but this time it is in Perfekt. Example (8) looks a lot like a sentence out of a written story, but the fact that it is part of a spoken interaction reinforces the idea that what determines the use of Präteritum and Perfekt is not based on the opposition between written vs. spoken, but it depends on the attitude of the speakers about the information they want to convey.

The last example analyzed is one of the numerous instances through the corpus in which both Perfekt and Präteritum are combined. The next extract comes from the deposition of Langbein Hermann and also displays a combination of the two tenses.

(9) "Ich möchte das an einem Beispiel illustrieren, das für uns sehr wichtig war. In Auschwitz wurde auf sehr vielerlei Art und Weise gestorben. Ich habe schon von den Vergasungen erzählt, die also auch an den kranken Häftlingen durchgeführt wurden. Es war auch eine ungeheure Gefahr für jeden Häftling, sich krank zu melden; auch bei uns im Stammlager, wo bei uns im Stammlager die Lebensbedingungen wesentlich besser waren als in Birkenau. Ich war dann einmal in Birkenau draußen und habe den Vergleich mit eigenen Augen gesehen. Ich habe inn auch in den Todeszahlen sehr deutlich gesehen. Wenn ein Häftling sich krank meldete, so war das so, daß er das in der Früh oder am Abend seinem Blockschreiber zu sagen hatte"

"I would like to give you an example, which was really important for us. In Auschwitz, people died in different ways. I have already told you about the gassings, which ware used also for the sick prisoners. It was also dangerous for every prisoner to report themselves for being sick, also in our general camp. Although in our general camp, the health conditions were way better than in Birkenau. I was once outside of Birkenau and I have seen the difference with my own eyes. I have also seen the numbers of deaths really well. When a prisoner reported himself for being sick, it was like, he had to say it to his block secretary".

The Perfekt is used here when the witness indicates that, he had already talked about the killing through gassing and that he had seen the difference between the major concentration camp and the one in Birkenau (the concentration camp called Auschwitz was formed by the combination of three separate camps: the general camp, also called Auschwitz I; Birkenau, also called Auschwitz II; and the work camp Monowitz, also called Auschwitz III). The information stated in Präteritum was a narration of what the prisoners had to do when they got sick. The different perspectives of the speaker about the information are expressed using both tenses. Like in the examples previously discussed, the shift in perspective is reflected by the change from Präteritum to Perfekt and vice versa.

The last set of charts displays some of the types of verbs in both tenses that were used with a very low frequency (once or twice). The total amount of verbs for each tense is six. 
1. Elisabeth Pickard

\begin{tabular}{|c|c|c|c|}
\hline Präteritum & Freq. & Perfekt & Freq. \\
\hline $\begin{array}{c}\text { bekommen } \\
\text { (to receive) }\end{array}$ & 1 & $\begin{array}{c}\text { abholen } \\
\text { (to pick up) }\end{array}$ & 1 \\
\hline $\begin{array}{c}\text { treffen } \\
\text { (to meet) }\end{array}$ & 1 & $\begin{array}{c}\text { brauchen } \\
\text { (to need) }\end{array}$ & 1 \\
\hline $\begin{array}{c}\text { angreiffen } \\
\text { (to attack) }\end{array}$ & 2 & $\begin{array}{c}\text { mitbringen } \\
\text { (to bring along) }\end{array}$ & 2 \\
\hline
\end{tabular}

\section{Konrad Morgen}

\begin{tabular}{|c|c|c|c|}
\hline Präteritum & Freq. & Perfekt & Freq. \\
\hline $\begin{array}{c}\text { anrufen } \\
\text { (to call by phone) }\end{array}$ & 1 & $\begin{array}{c}\text { anbieten } \\
\text { (to offer) }\end{array}$ & 1 \\
\hline $\begin{array}{c}\text { drücken } \\
\text { (to press) }\end{array}$ & 1 & $\begin{array}{c}\text { öffnen } \\
\text { (to open) }\end{array}$ & 1 \\
\hline $\begin{array}{c}\text { gehören } \\
\text { (to belong) }\end{array}$ & 2 & $\begin{array}{c}\text { mitbringen } \\
\text { (to bring along) }\end{array}$ & 2 \\
\hline
\end{tabular}

3. Otto Wolken

\begin{tabular}{|c|c|c|c|}
\hline Präteritum & Freq. & Perfekt & Freq. \\
\hline $\begin{array}{c}\text { beobachten } \\
\text { (to observe) }\end{array}$ & 1 & $\begin{array}{c}\text { putzen } \\
\text { (to clean) }\end{array}$ & 1 \\
\hline $\begin{array}{c}\text { protestieren } \\
\text { (to protest) }\end{array}$ & 1 & $\begin{array}{c}\text { schneiden } \\
\text { (to cut) }\end{array}$ & 1 \\
\hline $\begin{array}{c}\text { fahren } \\
\text { (to go) }\end{array}$ & 2 & $\begin{array}{c}\text { waschen } \\
\text { (to wash) }\end{array}$ & 2 \\
\hline
\end{tabular}

\section{Hermann Langbein}

\begin{tabular}{|c|c|c|c|}
\hline Präteritum & Freq. & Perfekt & Freq. \\
\hline $\begin{array}{c}\text { suchen } \\
\text { (to search) }\end{array}$ & 1 & $\begin{array}{c}\text { liefern } \\
\text { (to deliver) }\end{array}$ & 1 \\
\hline $\begin{array}{c}\text { zählen } \\
\text { (to count) }\end{array}$ & 1 & $\begin{array}{c}\text { senden } \\
\text { (to send) }\end{array}$ & 1 \\
\hline $\begin{array}{c}\text { schreiben } \\
\text { (to write) }\end{array}$ & 2 & $\begin{array}{c}\text { trennen } \\
\text { (to separate) }\end{array}$ & 2 \\
\hline
\end{tabular}

\section{Walter Petzold}

\begin{tabular}{|c|c|c|c|}
\hline Präteritum & Freq. & Perfekt & Freq. \\
\hline $\begin{array}{c}\text { bleiben } \\
\text { (to stay) }\end{array}$ & 1 & $\begin{array}{c}\text { laufen } \\
\text { (to walk, to run) }\end{array}$ & 1 \\
\hline $\begin{array}{c}\text { leben } \\
\text { (to live) }\end{array}$ & 1 & $\begin{array}{c}\text { werfen } \\
\text { (to throw) }\end{array}$ & 1 \\
\hline $\begin{array}{c}\text { hantieren } \\
\text { (to be busy) }\end{array}$ & 2 & $\begin{array}{c}\text { merken } \\
\text { (to notice) }\end{array}$ & 2 \\
\hline
\end{tabular}

Although the data from the first two sections of this chapter seem to be in line with what is traditionally claimed by different scholars about the use of the Präteritum in the spoken language, the small sample of the verb types included in these charts indicate that speakers use this tense with a large variety of verbs. The use of Präteritum with verbs other than sein, haben, and the modals suggests again that the choice of a tense instead of the other does not overlap with the opposition between the spoken vs. written language. The verbs in these charts provide further evidence for the pragmatic categories of comment and narration theorized by Weinrich (1964) and supported by other scholars such as Schumacher (2005), Welke (2010), and Concu (2016).

\section{PRELIMINARY CONCLUSIONS}

The textual analyses on the corpus included in this study have successfully challenged the depictions of the tenses Perfekt and Präteritum in DAF (Deutsch als Fremdsprache-German as a Foreign Language), and the traditional believes about the use of the Präteritum in spoken language, which was supposed to be limed to a small number of verbs. Furthermore, this research provides support for the pragmatic categories of comment and narration described by Weinrich (1964). First, data from the first set of charts demonstrate that German speakers often utilize the Präteritum in their spoken interactions, even with a higher frequency than the Perfekt. Second, the data from the second set of charts showed how the same verbs tend to appear often in a tense instead of the other. For instance, the verb sagen was used with higher frequency in Perfekt than in Präteritum, sehen was used equally in both tenses, and the verbs kommen and gehen were often used in the Präteritum. The data of the last charts have shown how the use of the Präteritum in spoken language is not limited to verbs such as sein and haben, and the modals. German speakers use this tense with a very large variety of verb types. The results of this analysis are also in line with what Concu (2016) has found for the written language in her corpus. The communicative intentions of the speakers are the ultimate factors that determine the difference between both Präteritum and Perfekt. The forms of Präteritum found in this corpus suggest that this tense is widely used in the spoken language, especially when speakers are requested to narrate events in the past. Furthermore, the numerous examples in which both the Perfekt and the Präteritum were used further reinforces Weinrich's claims on the close link between pragmatics and tense use. However, further research is needed to make even stronger claims about how the speakers' intention determines the use of the grammatical tenses. A bigger and, maybe, more recent corpus could, indeed, provide further evidence for Weinrich (1964), Schumacher (2005), Welke (2010), and Concu (2016). 


\section{REFERENCES}

Clark, E., 1990. "On the pragmatics of contrast". Journal of Child Language, 17, 417-431.

Helbig, G., Buscha, J., 2001. Deutsche Grammatik. Ein Handbuch für den Ausländerunterricht. München: Langenscheidt.

Concu, V., 2016. Toward the German Perfekt as an Emergent Structure. Interdisciplinary Journal for Germanic Linguistics and Semiotic Analysis, 21(1), 111-146.

Ehrich, V., 1992. Hier und jetzt. Tübingen: Max Niemeyer. Lombardi, A., 2008. "Tempus der Wissenschaft. Eine kontrastive Fallstudie zu deutschen und italienischen Artikeln des Annali-Korpus". In Heller, D. (Ed.), Formulierungsmuster in deutscher und italienischer Fachkommunikation: intra- und interlinguale Perspektiven. Bern: Peter Lang, 139-180.

Park, H. S., 2003. Tempusfunktionen in Texten. Frankfurt am Main: Peter Lang.

Roever, C., 2011. "Testing of second language pragmatics: Past and future". Language Testing. 28(4), October 2011, 463-481.
Rothstein, B., 2007. Tempus. Heidelberg: Universitätsverlag Winter.

Schumacher, N., 2005. Tempus als Lerngegenstand. Ein Modell für Deutsch als Fremdsprache und seine Anwendung für italienische Lernende. Tübingen: Gunter Narr.

Schumacher, N., 2011. "Nachzustand, Distanz und Aspektualität als Komponenten einer formfokussierten Steuerung von Perfekt und Präteritum". Linguistik online, 49(5), 2011.

Weinrich, H., 1964. Besprochene und erzählte Welt. Stuttgart: Kohlhammer.

Weinrich, H., 1993. Textgrammatik der deutschen Sprache. Mannheim, Leipzig, Wien, Zürich: Dudenverlag.

Welke, K., 2010. "Contra-Invarianz- Tempus im DAF (II): Perfekt und Präteritum". Deutsch als Fremdsprache, 2010/1, Hefte 47q.

Weerning, M., Mondello, M., 2004. Dies und Das. Grugliasco: Cibed. 